\title{
Evaluation of Loop-Mediated Isothermal Amplification for Rapid Detection of Erwinia amylovora on Pear and Apple Fruit Flowers
}

Todd N. Temple and Kenneth B. Johnson, Department of Botany \& Plant Pathology, Oregon State University, Corvallis 97331-2902

\begin{abstract}
Temple, T. N., and Johnson, K. B. 2011. Evaluation of loop-mediated isothermal amplification for rapid detection of Erwinia amylovora on pear and apple fruit flowers. Plant Dis. 95:423-430.

Fire blight of pear and apple is frequently an inoculum-limited disease but weather-based forecasting models commonly assume that the pathogen is omnipresent. To improve fire blight risk assessment during flowering, we developed a rapid pathogen detection protocol that uses loop-mediated isothermal amplification (LAMP) to detect DNA of epiphytic Erwinia amylovora on samples of pear and apple flowers. LAMP detected a single flower colonized epiphytically by E. amylovora in a sample of 100 flower clusters (approximately 600 flowers). Samples of 100 flower clusters from orchards (approximately one sample per hectare) were washed and subjected to LAMP, which was completed in $2 \mathrm{~h}$. In three experimental orchards inoculated with $E$. amylovora, positive LAMP reactions were attained from nine of nine 100-flower cluster samples; pathogen populations in the floral washes averaged $5.2 \times 10^{3} \mathrm{CFU}$ per flower as determined by dilution plating. Samples of pear and apple flowers obtained from 60 commercial or-

chards located in Oregon, Washington, California, and Utah resulted in detection of E. amylovora by LAMP assay from 34 sites, 20 of which developed fire blight. Of samples at early bloom, $10 \%$ were positive for epiphytic E. amylovora compared with $28 \%$ at petal fall; pathogen density in washes of positive samples averaged $3.2 \times 10^{2} \mathrm{CFU}$ per flower. In another 26 orchards, all floral washes were negative for $E$. amylovora by LAMP and by dilution plating; a light severity of fire blight was observed in 8 of these orchards. Overall, positive detection of epiphytic E. amylovora in commercial orchards by LAMP-based scouting generally occurred at later stages of bloom after heat (risk) units had begun to accumulate, an indication that weather-based forecasting models may be an adequate measure of fire blight risk for many orchardists. Nonetheless, several orchardists communicated that information from the LAMP-based rapid detection protocol resulted in modification of their fire blight management practices.
\end{abstract}

With the development of molecular tools for pathogen detection, there has been increased interest in using these tools in tactical disease management $(1,14,17,19,20,35)$. An important constraint to this purpose, however, is that many detection technologies require special equipment or processing with associated expense and delay. For example, with fire blight of pear and apple, protocols have been developed previously for detection of Erwinia amylovora through use of culture media $(9,15,23,34)$, enzyme-linked immunosorbent assay (7), and DNA amplification from floral washes via polymerase chain reaction (PCR; 2,21,29) but the methods are not used widely to determine the need for protective sprays because of issues with processing expense, assay sensitivity, or the time required to get an answer. The interest in obtaining knowledge of the presence or absence of epiphytic populations of E. amylovora on flowers relates to the significance of floral infection as a primary focal point in fire blight suppression $(11,31)$, and to the recognized sporadic nature of this highly destructive disease $(3,34)$. Sporadic outbreaks of fire blight are largely attributable to variability in epiphytic populations of the pathogen on flowers. In the Pacific Northwest region of the United States, the pathogen frequently is not present or is below damaging levels in orchards, even after weather-based forecasting models signal a risk of infection and the need for protective antibiotic treatments $(5,30)$.

The objectives of this research were to develop a rapid detection technology for E. amylovora and evaluate its potential for use in tactical disease management. The method of DNA detection we evaluated is termed loop-mediated isothermal amplification (LAMP; 27). Similar to PCR, this technique uses primers to detect

Corresponding author: K. B. Johnson,

E-mail: johnsonk@science.oregonstate.edu

Accepted for publication 22 November 2010.

doi:10.1094/PDIS-09-10-0636

(C) 2011 The American Phytopathological Society and amplify sequences of target DNA. Unlike PCR, a LAMP reaction does not require a thermocycler to carry the DNA amplification through specific temperature phases. Instead, the reaction is done isothermally (typically at $65^{\circ} \mathrm{C}$ ) in a heat block or water bath. LAMP has been shown to detect as few as 10 cells of a target organism (femtogram amounts of DNA) in a 1-h reaction (24). LAMP protocols have been developed previously to detect plant pathogens in environmental samples $(13,16,25,26,36)$. Recently, LAMP has been adapted for use with lateral-flow devices (36), which offers the potential for on-site use by nonspecialists $(4,24,35)$.

\section{Materials and Methods}

Bacterial strains. LAMP protocols for E. amylovora were developed using strain Ea153N, which is a spontaneous, nalidixicacid-resistant $(100 \mu \mathrm{g} / \mathrm{ml})$ mutant of a strain originally isolated from a canker on apple collected in Milton-Freewater, OR. Ea153N has been used as a representative isolate in numerous field studies $(10,12,32)$. Other bacterial strains used in this study are listed in Table 1; these strains, from a culture collection maintained by V. O. Stockwell and J. E. Loper (United States Department of Agriculture-Agricultural Research Service Horticultural Laboratory, Corvallis, OR), were used to evaluate the specificity of developed LAMP primers to E. amylovora.

DNA extraction. Bacterial cells in suspension $(1 \mathrm{ml})$ were pelleted by centrifugation (14,000 rpm for $2 \mathrm{~min}$ ) and resuspended in $200 \mu \mathrm{l}$ of InstaGene matrix (Bio-Rad Laboratories, Inc., Hercules, $\mathrm{CA}$ ). The cell mixture was vortexed for $5 \mathrm{~s}$ and incubated at $56^{\circ} \mathrm{C}$ for $20 \mathrm{~min}$ followed by boiling for $8 \mathrm{~min}$. After boiling, the mixture was centrifuged for $2 \mathrm{~min}$ at $10,000 \mathrm{rpm}$, and the supernatant was transferred to a mini-elute column (Epoch Biolabs, Inc., Sugarland, TX) and centrifuged for $1 \mathrm{~min}$ at 14,000 rpm.

LAMP. The LAMP protocol followed methods of Notomi et al. (27), with several modifications. Individual reactions were done in a 50- $\mu$ l volume consisting of a reagent mix, DNA, and polymerase. The reagent mix contained (with final concentrations) internal primers termed FIP and BIP $(24,27)(2.4 \mu \mathrm{M})$, outer primers termed $\mathrm{F}$ and $\mathrm{B}(0.2 \mu \mathrm{M})$, loop primer $(0.4 \mu \mathrm{M}$ when used $)$, dNTPs 
$(1.0 \mathrm{mM})$, betaine $(0.8 \mathrm{M})$, bovine serum albumin $(0.4 \mathrm{mg} / \mathrm{ml})$, ThermoPol buffer (1x; New England BioLabs, Beverly, MA), and $\mathrm{MgSO}_{4}(2 \mathrm{mM})$; this mix was allocated to each assay tube before the addition of double-stranded template DNA. Cell extracts $(5 \mu \mathrm{l})$ were used as template DNA; sterile water was used in the negative controls. Finally, 16 units $(2 \mu \mathrm{l})$ of Bst DNA polymerase (New England BioLabs, Ipswich, MA) were added to the reaction mix, followed by incubation at $65^{\circ} \mathrm{C}$ in a water bath or heat block. After $1 \mathrm{~h}$, reactions were assessed for DNA amplification by visual observation of turbidity in the assay tube; the turbidity is caused by a precipitate of magnesium pyrophosphate and is indicative of a positive LAMP assay $(24,27)$.

LAMP primer design. The DNA sequence of E. amylovora plasmid pEA29 was obtained from the National Center for Biotechnology Information (accession AF264948; 22). From this sequence, numerous sets of primers meeting the specifications for LAMP amplification were designed with the PrimerExplorer V4 software program (Fujitsu Ltd., Tokyo; http://primerexplorer.jp). Additional primers targeted to the chromosome of E. amylovora also were designed and evaluated but are not reported on here.

After initial testing, a LAMP primer set targeted to pEA29 of Ea153N was selected for further evaluation. Amplified products from positive LAMP assays were purified using a PCR product clean-up kit (ExoSAP-IT; USB Corp., Cleveland) and sequenced by the Oregon State University Center for Genome Research and Biocomputing. Sequenced products were compared with the pEA29 sequence used for LAMP primer design. LAMP products also were subjected to electrophoresis on agarose gels to establish a banding pattern to be used to confirm positive reactions in later experiments (27). The products were prepared for electrophoresis by double digestion with the restriction enzymes MluI and HaeIII (New England Biolabs, Ipswich, MA); digested LAMP products were run in 0.7 or $2.0 \%$ agarose at $70 \mathrm{~V}$ for $1 \mathrm{~h}$ and visualized on an ultraviolet gel imager (UVP Transilluminator, Cambridge).

Primer sensitivity and specificity. Sensitivity of the pEA29 LAMP primer set was assessed by observing amplification of DNA extracted from a serial dilution of cultured Ea153N, and also by serial dilution of extracted DNA. Dilution endpoint turbidity was evaluated with a NanoDrop spectrophotometer (Thermo Scientific, Wilmington, DE) at an optical density of $400 \mathrm{~nm}$ (24,27), and by visual inspection. Specificity of the pEA29 LAMP primer set was tested against DNA from various species of plant-associated enteric bacteria and other species commonly associated with pome fruit flowers (28,33), including additional isolates of $E$. amylovora (Table 1). Cell suspensions of these species were prepared at $5 \times$ $10^{5} \mathrm{CFU} / \mathrm{ml}$ and boiled for $10 \mathrm{~min} ; 5 \mu$ of a boiled suspension was used as a template for LAMP as described above.

Effect of flowers on LAMP detection of $\boldsymbol{E}$. amylovora. Flowers of pear 'Bartlett' or apple 'Gala' or 'Red Delicious' were col- lected in April 2008 and 2009 from experimental orchards located at the Oregon State University, Department of Botany and Plant Pathology Field Laboratory near Corvallis. Distilled water (3 liters) in plastic pails was amended with flowers at densities of $0,10,100$, or 1,000 per pail. Freeze-dried Ea153N (with known titer) was added to the pails and thoroughly mixed with the water and flowers to achieve final concentrations of approximately 0,500 , or 5,000 $\mathrm{CFU} / \mathrm{ml}$ at each flower density. Subsamples $(1 \mathrm{ml})$ of each suspension was diluted serially onto CCT medium (9) amended with nalidixic acid at $75 \mu \mathrm{g} / \mathrm{ml}$ to enumerate Ea153N, and onto Pseudomonas agar F (PAF; Difco Laboratories, Detroit) amended with cycloheximide at $50 \mu \mathrm{g} / \mathrm{ml}$ to enumerate total bacterial populations. Samples were prepared for LAMP by first filtering 1 liter of each suspension through four layers of cheesecloth and then through a 35- $\mu \mathrm{m}$ microsieve (Biodesign Inc., Carmel, NY). The filtered suspension (15 to $30 \mathrm{ml}$ ) was concentrated by embedding on a $0.2-\mu \mathrm{m}$ membrane (Supor 200; Pall Life Sciences, Port Washington, NY). Cells captured on the membrane were resuspended in $1 \mathrm{ml}$ of sterile water, which was subjected to DNA extraction and a LAMP assay as described above. The experiment was replicated five times with both pear and apple flowers.

Single infested flower experiment. Stigmas on individual, newly opened, detached pear (Bartlett) or apple (Gala) flowers were inoculated with a suspension of Ea153N prepared at $5 \times 10^{5}$ $\mathrm{CFU} / \mathrm{ml}$. Inoculated flowers were held in 2-ml plastic tubes with the proximal end of the pedicel (1.5 to $2 \mathrm{~cm}$ in length) submerged in water and incubated for 3 to 4 days at $16^{\circ} \mathrm{C}$ inside of a plastic crisper box lined on the bottom with moistened paper towel. After incubation, stigmas of inoculated flowers were removed and placed in $1 \mathrm{ml}$ of sterile water; a $10-\mu \mathrm{l}$ subsample was dilution plated onto CCT medium to estimate the pathogen population size. The wash and stigmas were then added to either 1.5 liter (2008) or $300 \mathrm{ml}$ (2009) of tap water or to 100 flower clusters (field-collected, 6 flowers per cluster) in 1.5 liter (2008) or $300 \mathrm{ml}$ (2009) of tap water, which were held in 33-by-45-cm, resealable plastic bags (Minigrip, Kennesaw, GA). Water-alone and noninoculated 100-flower cluster samples in water were included as controls. Bags with flowers were vigorously hand massaged for $15 \mathrm{~s}$, followed by sonication (Model 2200; Branson, Danbury, CT) for 2 min. As described above, the wash suspensions were prefiltered, embedded on a $0.2-$ $\mu \mathrm{m}$ membrane, resuspended in $1 \mathrm{ml}$ of water, and subjected to DNA extraction and a LAMP assay.

Experimental orchard sampling. Pear and apple flowers from research orchards (0.25 to 0.5 ha) located at the Botany and Plant Pathology Field Laboratory were sampled and subjected to LAMP assay. Some orchards were being used for fire blight control experiments and had been inoculated with Ea153N at full bloom by misting each tree with 2 liters of an aqueous suspension prepared at 5 $\times 10^{5} \mathrm{CFU} / \mathrm{ml}$. Flowers for the LAMP assay were sampled $4(2008$

Table 1. Specificity evaluation of primers designed for detection of Erwinia amylovora by loop-mediated isothermal DNA amplification (LAMP) with plantassociated enteric bacteria and other species commonly associated with pome fruit flowers

\begin{tabular}{lcc}
\hline & No. of strains with positive LAMP assay of total strains tested \\
\cline { 2 - 3 } Strain identity & LAMP pEA29 primer set & $1^{\mathrm{b}}$ of 2 \\
\hline Bacillus cereus & 0 of 2 & 0 of 1 \\
B. subtilis & 0 of 1 & 0 of 1 \\
Dickeya spp. & 0 of 1 & 8 of 8 \\
Erwinia amylovora & 8 of 8 & $1^{\mathrm{b}}$ of 2 \\
E. amylovora (lacking plasmid pEA29) & 0 of 2 & 0 of 2 \\
E. persicina & 0 of 2 & 0 of 2 \\
E. tasmaniensis & 0 of 2 & 0 of 1 \\
Methylobacterium spp. & 0 of 1 & $2^{\mathrm{b}}$ of 3 \\
Pantoea agglomerans & 0 of 3 & 0 of 3 \\
Pectobacterium atrosepticum & 0 of 3 & 0 of 1 \\
Pseudomonas fluorescens & 0 of 1 & 0 of 1 \\
P. putida & 0 of 1 & 0 of 3 \\
P. syringae & 0 of 3 & \\
\hline a Based on sequencing of the 16S-23S rRNA intergenic spacer region. & \\
b Possible mispriming. & &
\end{tabular}


and 2009) and 9 (2008 only) days after inoculation. Noninoculated orchards were sampled at the same times. In each orchard, three 100flower cluster samples were collected in 33-by-45-cm resealable plastic bags. Flower clusters were collected haphazardly along Wshaped transects through the orchards. Several clusters were sampled from most trees in each block. In the laboratory, the 100-flower cluster samples were washed and processed for dilution plating and LAMP assay as described in previous sections; the floral wash volume was 1.5 liter of water in 2008 and $300 \mathrm{ml}$ in 2009.

Commercial orchard survey. From 2008 to 2010, flowers from 54 commercial pear and apple orchards (most of which were approximately 5 ha in size and located in major fruit-production districts of Oregon, Washington, and California) were sampled and subjected to LAMP and dilution-plating assays. Orchards selected for sampling were identified with the help of cooperators in each fruit-production district. The sampling methodology was similar to that used in experimental orchard blocks in Corvallis, except that the cooperators were instructed to take five 100-flower cluster samples in each orchard (one per hectare per sampling date) and to sample each orchard three times: mid-bloom, full bloom, and petal fall. However, because of time constraints for some cooperators, approximately $25 \%$ of orchards were sampled less thoroughly; however, at a minimum, orchards in this study were sampled twice with at least three 100-cluster samples per orchard on each sampling date. A W-shaped sampling transect was used to collect the samples; generally, one cluster was collected every few trees. Flower samples were shipped overnight to Corvallis for processing in our laboratory. Flowers were washed in 1.5 liters of water in 2008 but wash volumes were reduced to $300 \mathrm{ml}$ in 2009 and 2010 based on inconsistent results between the LAMP assay and dilution-plate methods in 2008. Inconsistency among methods in 2008 was rectified by a fourfold SpeedVac (model DNA 120; Thermo Savant, Holbrook, NY) concentration of extracted DNA prior to the LAMP assay. In 2009, additional flower samples were collected from six apple orchards in Utah. Sampling in Utah differed from the other locations in that only one 100-flower cluster sample was collected per orchard per sample date but sampling was done daily, resulting in 10 to 12 samples per orchard.

Data on the development of fire blight in sampled orchards were collected by cooperators in late June to early July. Orchards were inspected and scored for fire blight severity: none, light $(\leq 1$ infection [strike] per tree), medium ( 2 to 5 strikes per tree), and heavy ( $\geq 6$ strikes per tree).

Data analysis. Data from experiments to evaluate LAMP sensitivity were plotted as the concentration of template from Ea153N (CFU or concentration of extracted DNA) and turbidity as measured by the NanoDrop spectrophotometer (optical density at 400 $\left.\mathrm{nm}\left[\mathrm{OD}_{400}\right]\right)$. Because LAMP assay is a presence or absence test, assay results from laboratory experiments and the experimental orchards yielded qualitative results with no variation among replications; thus, data were simply tabulated. Estimates of the population size of E. amylovora recovered on dilution plates were transformed $\log _{10}(y)(8)$ and reported as mean $\log (\mathrm{CFU})$ per milliliter or per flower as dictated by the experiment; arithmetic means presented in the text were backtransformed from mean log (CFU) per milliliter or per flower.

Results of LAMP assays and dilution plating performed on 100flower cluster samples from commercial orchards were summa- rized by production district and by bloom stage at the time of sampling. The value of the CougarBlight (30) risk assessment model also was calculated for each sampling date. For this purpose, the temperature data for each fruit district were obtained from records of local cooperative weather networks, which are maintained in databases by the Oregon State University Integrated Plant Protection Center. Dates with a negative detection or with one or more positive detections of E. amylovora by LAMP were plotted along composite, seasonal summaries of the CougarBlight risk index. Composite summaries were accomplished by plotting CougarBlight values for production areas in California, Oregon, and Washington for the time period when they where being sampled; risks values were averaged during periods when more that one district was sampled.

\section{Results}

Evaluation of sensitivity and specificity. The LAMP primer set (i.e., primers Fip, Bip, F, and B but not the loop primer) targeted to plasmid pEA29 of E. amylovora (Table 2) provided positive reactions for strain Ea153N and other strains of E. amylovora with pEA29 but did not react with two pathogen strains that lacked the plasmid (Table 1). The sequenced LAMP products from Ea153N showed $100 \%$ homology to the sequence for which the primers were designed. A serial dilution of cultured cells of Ea153N resulted in positive LAMP reactions from $9.9 \times 10^{9}$ to a statistically significant $(P \leq 0.05)$ endpoint of $200 \mathrm{CFU} / \mathrm{ml}$, as determined by the Nanodrop spectrophotometer (Fig. 1A). At cell densities of 2 and $20 \mathrm{CFU} / \mathrm{ml}$, however, results of the LAMP assays were concluded to be negative (absorbance values statistically similar to water controls: 0.003 to 0.017 , respectively, at $\mathrm{OD}_{400}$ ). Overall, macroscopic detection of turbidity produced by a positive LAMP assay also required a cell suspension of $\geq 200 \mathrm{CFU} / \mathrm{ml}$. The dilution series of DNA from E. amylovora resulted in positive LAMP assays at concentrations ranging from $114 \mu \mathrm{g} / \mu \mathrm{l}$ to an endpoint of $500 \mathrm{fg} / \mu \mathrm{l}$ (Fig. 1B). Macroscopic visualization of turbidity required $\geq 5 \mathrm{pg} / \mu \mathrm{l}$ of DNA. Water controls were negative for turbidity by spectrophotometer or amplifiable products when run on an agarose gel (data not shown).

None of the other bacterial strains tested reacted positively with the pEA29-targeted primer set that included Fip, Bip, F, and B (Table 1). The addition of a loop primer (Table 2), however, resulted in positive amplification with one of the two strains of $E$. amylovora lacking pEA29, one of the two strains of Bacillus cereus, and two of the three strains of Pantoea agglomerans (Table 1). As a result, use of the loop primer was discontinued.

Effect of flowers on detection of the pathogen with LAMP. Indigenous bacteria were recovered from the 3-liter volumes of water at population sizes consistent with the number of pear or apple flowers added to the suspensions; the range was below detection for water only to $1.2 \times 10^{5} \mathrm{CFU} / \mathrm{ml}$ in 3-liter volumes to which 1,000 flowers had been added. For water only or water with flowers, LAMP reactions and dilution plates were negative for detection of E. amylovora. Strain Ea153N was always detected by LAMP assay from suspensions to which it had been amended regardless of the density of pear or apple flowers (Table 3). Ea153N also was recovered by dilution plating where counts of viable cells of CTT medium averaged $2.5 \times 10^{2}$ and $1.8 \times 10^{3} \mathrm{CFU} / \mathrm{ml}$ in the lower and higher pathogen-amended suspensions, respectively

Table 2. Primers designed for detection of Erwinia amylovora by loop-mediated isothermal DNA amplification targeted to a hypothetical protein region of plasmid pEA29a

\begin{tabular}{ll}
\hline Primer name & \multicolumn{1}{c}{ Primer sequence $\left(\mathbf{5}^{\prime}\right.$ to $\left.\mathbf{3}^{\prime}\right)$} \\
\hline Fip & TCGTGGTTATGCGATAACGCGTCAGGAACTCCAGGGAGGTC \\
Bip & TGTGTCACGATCCAGAGCACACGGTCATATGCAGGAGCAAGT \\
F & ACGCAAGCCTTCTAAAGCT \\
B & ATGGCCCGTGAAAAAGTCA \\
Loop & GGGGGAGAGTCCATTTGGA \\
\hline
\end{tabular}

a Primer concentrations in the reaction mix were $2.4 \mu \mathrm{M}$ for Fip and Bip, $0.2 \mu \mathrm{M}$ for $\mathrm{F}$ and $\mathrm{B}$, and $0.4 \mu \mathrm{M}$ for Loop. Melting temperatures for the primers were between 59 and $60^{\circ} \mathrm{C}$. National Center for Biotechnology Information accession no. AF264948; bases 10,912 to 11,122 (22). 
(Table 3). The presence of LAMP assay products was confirmed by electrophoresis on agarose gels (data not shown).

Single infested flower experiment. Single inoculated apple and pear flowers were colonized epiphytically by Ea153N at $4.1 \times 10^{6}$ to $7.1 \times 10^{7} \mathrm{CFU}$ per flower (Table 4); these flowers were the source of pathogen in the 1.5-liter (2008) and 300-ml (2009) suspensions of water subjected to the LAMP assay. A positive LAMP assay resulted for all replications of a pathogen-infested pear or apple flower added to water only or to water amended with 100 pear or apple flower clusters (Table 4). LAMP assays and dilution plates for detection of E. amylovora were negative for water only and for washes of field-sampled pear or apple flowers only. Adding 100 flower clusters (approximately 600 flowers) to the wash water resulted in recovery of indigenous bacteria at population sizes that

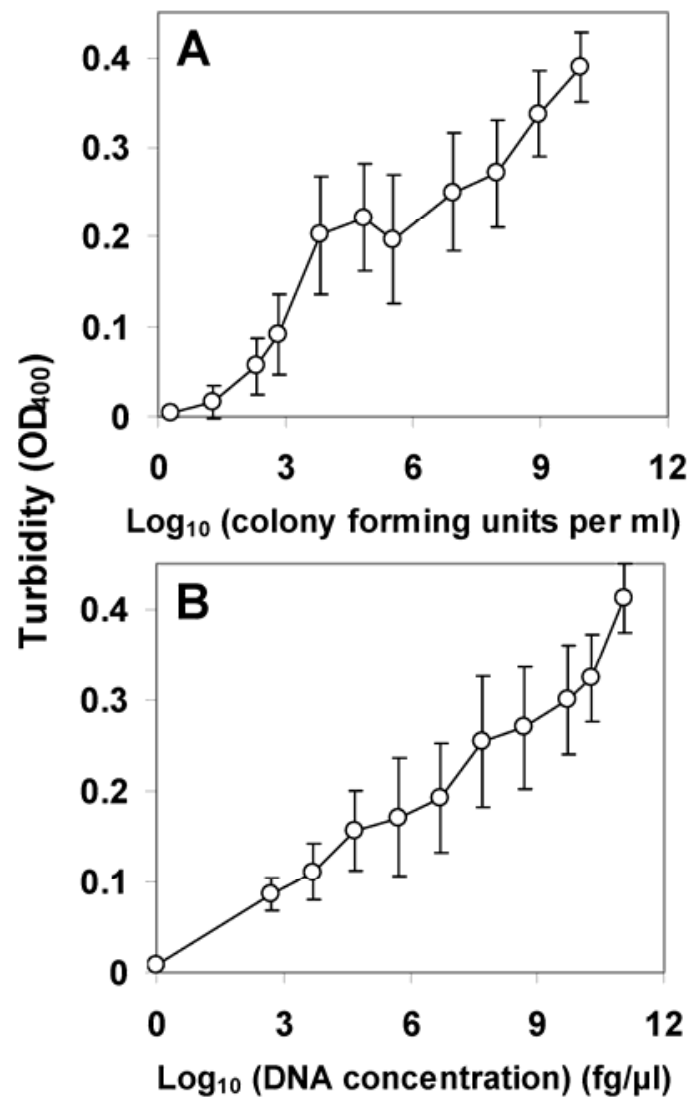

Fig. 1. Endpoint absorbance readings of turbidity at optical density of $400 \mathrm{~nm}$ $\left(O D_{400}\right)$ for loop-mediated isothermal DNA amplification assays performed on: $A$, a dilution series of cultured cells of Erwinia amylovora strain Ea153N boiled for 10 min after dilution and $\mathbf{B}$, a dilution series of DNA extracted from $E$. amylovora Ea153N. Each data point is the mean of five replications; error bars represent \pm one standard deviation of the mean. ranged from $3.3 \times 10^{2}$ to $6.0 \times 10^{3} \mathrm{CFU}$ per flower (data not shown).

Experimental orchard sampling. Flower clusters sampled at full bloom (2008 and 2009) and at petal fall (2008 only) from noninoculated pear and apple orchards resulted in negative LAMP reactions (Table 5). Similarly, E. amylovora was not detected on dilution plates but indigenous bacteria were recovered from the floral washes at $2.5 \times 10^{4}$ to $1.6 \times 10^{6} \mathrm{CFU}$ per flower (Table 5). In contrast, all 100-flower cluster samples from apple and pear orchards inoculated with Ea153N resulted in positive LAMP reactions (Table 5).

Commercial orchard survey. The 2008 sampling of commercial orchards in Oregon's Rogue Valley and Hood River Valley fruit-production districts was a first attempt to detect epiphytic $E$. amylovora without its artificial introduction onto pear and apple flowers. The pathogen was not detected by either LAMP or dilution-plate assay in the Rogue Valley (Table 6) but was detected by dilution plating of some samples from the Hood River Valley. For the Hood River Valley, 33\% of samples from full bloom and petal fall samples were positive by dilution plating, with population size averaging $40 \mathrm{CFU}$ per flower. Initially, all LAMP assays were negative but, after the DNA extracted from the 100-flower cluster samples was concentrated fourfold by SpeedVac evaporation, positive LAMP assays were obtained for the same samples that were positive by dilution plate. Consequently, in 2009 and 2010, the volume of water used to wash the 100 -flower cluster samples was reduced from 1.5 liter (2008) to 0.3 liter.

In commercial orchards surveyed in 2009 and 2010, E. amylovora was detected by LAMP in 17\% (120 of 714) of 100-flower cluster samples, and the frequency of detection again varied among orchard, production district, and year (Table 6). Overall, when detected by dilution plating, the population size of $E$. amylovora averaged $7.9 \times 10^{2} \mathrm{CFU}$ per flower. Moreover, if the fire blight pathogen was detected by dilution plating (100 of 676 samples containing 100 flower clusters [14.7\%]), it was also detected by LAMP (note: dilution-plating data were missing for 38 of the 714 samples). In contrast, for 11 flower cluster samples (1.6\% of total samples), a positive LAMP was obtained but dilution plating was negative. The likelihood of detecting E. amylovora in 100-flower cluster samples also depended on the sample timing, with the mean incidence of positive LAMP assays approximately tripling at petal fall compared with midbloom (Table 6).

Although fire blight was observed by cooperators in 28 of 60 orchards, with severity classified as light ( $\leq 1$ strike per tree) in 21 of 28 orchards, several orchards in the Hood River Valley in 2008 and the Columbia Basin and Utah in 2009 experienced significant epidemics. Overall, fire blight was observed in 20 orchards where $E$. amylovora was detected by LAMP during bloom, and LAMP detected E. amylovora in an additional 14 orchards where blight was not observed. Sixteen orchards were negative for LAMP and for fire blight. Of the eight orchards where LAMP did not detect the pathogen in a100-flower cluster sample but a light severity of symptoms appeared, seven were central-Washington apple or-

Table 3. Percentage of positive loop-mediated isothermal DNA amplification (LAMP) assays as influenced by concentration of Erwinia amylovora strain Ea153N and density of pear of apple flowers in the wash suspension ${ }^{\mathrm{a}}$

\begin{tabular}{|c|c|c|c|c|}
\hline \multirow[b]{2}{*}{ Cultivar, conc. $(\mathrm{CFU} / \mathrm{ml})^{\mathrm{c}}$} & \multicolumn{4}{|c|}{ Positive LAMP assays ( \%) per flower density in 3-liter suspension of waterb } \\
\hline & $\mathbf{0}$ & 10 & 100 & 1,000 \\
\hline \multicolumn{5}{|l|}{ Bartlett pear } \\
\hline 0 & 0 & 0 & 0 & 0 \\
\hline $2.5 \times 10^{2}$ & 100 & 100 & 100 & 100 \\
\hline $1.8 \times 10^{3}$ & 100 & 100 & 100 & 100 \\
\hline \multicolumn{5}{|l|}{ Gala Apple } \\
\hline 0 & 0 & 0 & 0 & 0 \\
\hline $2.5 \times 10^{2}$ & 100 & 100 & 100 & 100 \\
\hline $1.8 \times 10^{3}$ & 100 & 100 & 100 & 100 \\
\hline
\end{tabular}

${ }^{a}$ Field-grown flowers collected from experimental orchards located at the Botany and Plant Pathology Field Laboratory, Oregon State University, Corvallis.

${ }^{\mathrm{b}}$ Each mean is the average of five replications.

${ }^{c}$ Concentration of viable Ea153N in suspension, determined by dilution plating the wash suspension onto CCT medium (9). 
chards planted to cultivars (e.g., Pink Lady) prone to secondary bloom (5). For five of these orchards, samples were not taken at petal fall of the primary bloom period or during the secondary bloom.

For each year of sampling in commercial orchards, the comparison of positive and negative detection of E. amylovora in an orchard by LAMP with a weather-based fire-blight-forecasting model, CougarBlight, revealed that the outcome of the LAMP assay tended to segregate with the disease risk at the time of sampling (Fig. 2). For samples positive by LAMP, the CougarBlight 4day degree-hour accumulation $\left({ }^{\circ} \mathrm{C}\right.$ ) averaged $144 \pm 155$ (standard deviation); degree-hour accumulations for samples negative by LAMP averaged $64 \pm 143$.

\section{Discussion}

We developed a LAMP assay targeted to the pEA29 plasmid of E. amylovora, and evaluated the ability of this assay to detect the pathogen in washes of pear and apple flowers where it grows epiphytically as a prerequisite to infection of these hosts. Our guiding rationale for this effort was that information on the presence or absence of the fire blight pathogen in a local floral population could potentially improve tactical fire blight management and lessen destructive losses cause by this disease. Although the LAMP assay proved to be rapid, adequately sensitive, specific for our purpose, and relatively inexpensive and easy to perform, we were not fully convinced that sampling pear and apples flowers and shipping them for analysis by LAMP assay in a central laboratory facility is ready for widespread application. Nonetheless, the re- sults of this study are useful for what they revealed about the epidemiology of fire blight within the Pacific Northwest, and for clarifying how molecular detection technologies and their delivery to stakeholders need to improve to achieve a practical test for the presence E. amylovora at the level of the individual orchard.

The LAMP assay, involving four to six primers, has proven to be robust when applied to environmental samples (Tables 3, 5, 6) $(4,13,24,36)$. Less apparent is the effort that goes into the initial screening of LAMP primers. We designed and screened 45 primer sets (including some designed for chromosomal targets of $E$. amylovora not reported on here), which resulted in a substantial investment of time and materials as sets were tested and discarded. Overall, the pEA29 primers used in this study appeared to meet the criteria for specific and sensitive detection of E. amylovora from populations of pear and apple flowers. We chose primers targeted to the pEA29 plasmid because of its uniqueness to E. amylovora and its near ubiquity in strains of the pathogen sampled from the region. Occasionally, strains of E. amylovora that lack this plasmid have been isolated but they are generally rare (3 to $6 \%$ of isolates from the Pacific Northwest; V. O. Stockwell, unpublished data, 18). We developed a loop primer for the pEA29 primer set to shorten the time required to visualize a positive LAMP assay but, in specificity testing, we experienced possible mispriming with its use, particularly with the common epiphyte $P$. agglomerans (Table 1) $(27,32)$.

Sensitivity of the LAMP assay decreased somewhat as the sample complexity increased. For example, $200 \mathrm{CFU} / \mathrm{ml}$ was the minimum density of pathogen cells from pure culture required to

Table 4. Percentage of positive loop-mediated isothermal DNA amplification (LAMP) assays from a single flower colonized by Erwinia amylovora strain Ea153N as influenced by presence or absence of pear or apple flowers in the wash suspension ${ }^{\mathrm{a}}$

\begin{tabular}{|c|c|c|c|c|}
\hline \multirow[b]{3}{*}{ Year, cultivar } & \multicolumn{4}{|c|}{ Positive LAMP assays (\%) per treatment added to water ${ }^{b}$} \\
\hline & \multirow[b]{2}{*}{ Water only } & \multirow[b]{2}{*}{ 100-flower clusters } & \multicolumn{2}{|c|}{ Single flower colonized by } \\
\hline & & & Ea153N & Ea153N with 100-flower clusters \\
\hline \multicolumn{5}{|l|}{2008} \\
\hline Bartlett pear & 0 & 0 & $100(7.3 \pm 0.50)$ & $100(7.0 \pm 0.71)$ \\
\hline Gala apple & 0 & 0 & $100(6.8 \pm 0.87)$ & $100(6.6 \pm 1.07)$ \\
\hline \multicolumn{5}{|l|}{2009} \\
\hline Bartlett pear & 0 & 0 & $100(6.6 \pm 1.11)$ & $100(6.4 \pm 0.56)$ \\
\hline Gala apple & 0 & 0 & $100(6.4 \pm 1.79)$ & $100(7.8 \pm 0.17)$ \\
\hline
\end{tabular}

a Stigmas on a newly opened, detached pear or apple flowers were inoculated with Ea153N and incubated for 3 to 4 days prior to the LAMP assay performed on the wash suspension. Field-grown flowers were collected from experimental orchards located at the Botany and Plant Pathology Field Laboratory, Oregon State University, Corvallis; 100-flower clusters per 0.3 (2009) or 1.5 liter (2008) volume were in a resealable plastic bag.

${ }^{\mathrm{b}}$ Three experimental replications each year. $\log _{10}$ population size (CFU per flower) and standard deviation of strain Ea153N on single flowers added to 1.5 (2008) or 0.3 (2009) liters of water. Pathogen population size was determined by dilution plating the wash suspension onto CCT medium (9).

Table 5. Results of loop-mediated isothermal DNA amplification (LAMP) assays performed on 100-flower cluster samples from experimental pear and apple orchards located near Corvallis, OR, which were inoculated or not inoculated with Erwinia amylovora ${ }^{\text {a }}$

\begin{tabular}{|c|c|c|c|c|}
\hline \multirow[b]{2}{*}{ Year, orchard cultivar } & \multirow[b]{2}{*}{ Inoculated $^{\mathrm{c}}$} & \multirow[b]{2}{*}{ Positive/total $^{\mathrm{d}}$} & \multicolumn{2}{|c|}{ Population size $\log _{10}(\mathrm{CFU} / \text { flower })^{b}$} \\
\hline & & & E. amylovora & Total bacteria \\
\hline \multicolumn{5}{|l|}{2008} \\
\hline Bartlett pear & No & 0 of 6 & Not detected & $5.6 \pm 0.10$ \\
\hline Fuji apple & No & 0 of 6 & Not detected & $4.7 \pm 0.29$ \\
\hline Jonathon apple & No & 0 of 6 & Not detected & $4.6 \pm 0.15$ \\
\hline Bartlett pear & Yes & 6 of 6 & $2.7 \pm 0.70$ & $5.2 \pm 0.30$ \\
\hline Gala apple & Yes & 6 of 6 & $3.7 \pm 0.53$ & $4.4 \pm 0.24$ \\
\hline Golden Delicious apple & Yes & 6 of 6 & $4.5 \pm 0.16$ & $5.0 \pm 0.28$ \\
\hline \multicolumn{5}{|l|}{2009} \\
\hline Bartlett pear & No & 0 of 3 & Not detected & $4.4 \pm 0.41$ \\
\hline Mixed pear & No & 0 of 3 & Not detected & $4.7 \pm 0.16$ \\
\hline Braeburn apple & No & 0 of 3 & Not detected & $4.7 \pm 0.08$ \\
\hline Bartlett pear & Yes & 3 of 3 & $3.8 \pm 0.07$ & $6.2 \pm 0.24$ \\
\hline Gala apple & Yes & 3 of 3 & $3.6 \pm 0.05$ & $5.4 \pm 0.05$ \\
\hline
\end{tabular}

a Orchards were located at the Oregon State University, Botany and Plant Pathology Field Laboratory; 100-flower cluster samples (approximately 600 flowers) were suspended in 1.5 (2008) or 0.3 liter (2009) volumes of water.

${ }^{\mathrm{b}}$ E. amylovora population size was determined by dilution plating the wash suspension onto CCT medium (9) and total bacterial population size was determined by dilution plating the wash suspension onto Pseudomonas agar F. Population size \pm standard deviation among 100-flower cluster samples.

${ }^{\mathrm{c}}$ Indicates if trees in orchards were mist inoculated with a suspension of stain Ea153N at full bloom.

${ }^{\mathrm{d}}$ Number of positive LAMP assays of total samples. 
visualize a positive LAMP assay without aid of a spectrophotometer. In contrast, the first efforts with Ea153N in suspension with flowers failed to detect the pathogen at $250 \mathrm{CFU} / \mathrm{ml}$ (data not shown). This prompted the use of the intermediate concentration step, where a $15-\mathrm{ml}$ subsample of the prefiltered wash was embedded on $0.2-\mu \mathrm{m}$ membrane, resulting in detection of the pathogen at $2.5 \times 10^{2} \mathrm{CFU} / \mathrm{ml}$ regardless of floral density (Table 3 ). Similarly, several 2008 samples from commercial orchards in the Hood River Valley resulted in detection by dilution plate but not by LAMP (Table 6); this prompted the reduction in the floral wash volume from 1.5 to 0.3 liters. In the 2009 and 2010 commercial orchard surveys, use of the 0.3 -liter wash volume with the embedded filter concentration step resulted in similar rates of pathogen detection and high sample congruence between the LAMP and dilution plating methods. Therefore, we concluded that the LAMP protocol has a detection limit of approximately $10^{3} \mathrm{CFU} / \mathrm{ml}$ when $300 \mathrm{ml}$ of water is used to wash the 100 -flower cluster sample, and approximately $10^{2} \mathrm{CFU} / \mathrm{ml}$ when $15 \mathrm{ml}$ of the floral wash is reduced to 1 $\mathrm{ml}$ by filter concentration.

We used a heuristic approach to determine the number of flower clusters to include in a sample and the number of samples to make in each orchard, mostly because we had little prior knowledge of the size of epiphytic populations of E. amylovora in commercial orchards across the region. We required an orchard sample that would be large enough to detect a potentially significant (diseasecausing) population of E. amylovora but simple enough for a cooperator in the field to understand and implement. In a study with a similar objective, Kritzman et al. (15) used preliminary sampling from two orchards and statistical theory to examine the problem of sample size for detection of epiphytic E. amylovora on individual flowers. The conditions of their study, however, differed greatly from ours in that their optimal sample size determination was based on orchards where 10 to $40 \%$ of individual flowers were colonized by E. amylovora, and 15 to $20 \%$ of flower clusters became diseased. This high level of pathogen infestation led to the conclusion that a 20 -flower sample from a few trees was sufficient to achieve an accuracy level within $10 \%$ of the true mean (15). In contrast, we detected the pathogen in only $130(16 \%)$ of 788100 flower cluster samples (600 flowers) from 60 commercial orchards and, from data provided by cooperators, we estimated the mean observed incidence of diseased flower clusters to be in the range of 0.01 to $0.1 \%$. For our study, if a hectare from which a positive LAMP assay can be obtained is assumed to be randomly distributed (a 100-flower cluster sample represented approximately one hectare) then, from binomial probability tables (6), the probability of not detecting E. amylovora is $7.5 \%$ when the true mean is 0.16 (16\% of hectares have a detectable epiphytic E. amylovora population) and 15 LAMP assays are conducted per 5-ha orchard. The distribution of positive LAMP samples, however, likely deviates somewhat from random (Table 6) (15). Although it is beyond the scope of this study, the variability of epiphytic E. amylovora populations and potential for aggregation among samples requires further investigation relative to factors that appear to influence the probability of a positive sample: individual fruit-production district (Table 6), the bloom stage at the time of sampling (Table 6), the disease history of an orchard (30), and the weather-based prediction of fire blight risk (Fig. 2).

Heat unit accumulation models (e.g., Cougarblight; 30) that identify when conditions are favorable for E. amylovora to grow on and disperse among pome fruit flowers are the principal tool used by growers and advisors to determine the need for protective antibiotic sprays (30). Consequently, it was expected that orchards testing positive by LAMP assay on a given sampling date (defined as at least one positive sample of 100 flower clusters per orchard) would tend to be associated with periods of higher disease risk (Fig. 2). More interesting were the many negative LAMP assays

Table 6. Summary of loop-mediated isothermal DNA amplification (LAMP) assays performed to detect Erwinia amylovora in 100-flower cluster samples collected from commercial pear and apple orchards in the Pacific Northwest region of the United States from 2008 to $2010^{\mathrm{a}}$

\begin{tabular}{|c|c|c|c|c|c|c|c|c|c|c|}
\hline \multirow[b]{2}{*}{ Year, state } & \multirow[b]{2}{*}{ Production area } & \multirow[b]{2}{*}{ Host } & \multirow[b]{2}{*}{$\begin{array}{c}\text { No. of } \\
\text { orchards }\end{array}$} & \multicolumn{3}{|c|}{$\begin{array}{l}\text { No. of positive LAMP assays of total } \\
100 \text {-flower cluster samples }\end{array}$} & \multirow[b]{2}{*}{$\begin{array}{c}\text { Isolation } \\
\text { on media }\end{array}$} & \multirow[b]{2}{*}{$\begin{array}{l}\text { CFU per } \\
\text { flower }^{\text {d }}\end{array}$} & \multirow[b]{2}{*}{$\begin{array}{l}\text { No. with } \\
\text { fire blight }\end{array}$} & \multirow[b]{2}{*}{ Severity $^{f}$} \\
\hline & & & & $\begin{array}{l}\text { Mid- } \\
\text { bloom }\end{array}$ & $\begin{array}{c}\text { Full } \\
\text { bloom }\end{array}$ & $\begin{array}{c}\text { Petal } \\
\text { fall }\end{array}$ & & & & \\
\hline \multicolumn{11}{|l|}{2008} \\
\hline \multirow[t]{2}{*}{ Oregon } & Rogue Valley & Pear & 3 & 0 of 15 & 0 of 14 & - & No & - & 0 & - \\
\hline & Hood River Valley & Pear & 3 & 0 of 15 & $3^{g}$ of 15 & $7^{g}$ of 15 & Yes & 1.6 & 2 & Light to mod \\
\hline \multicolumn{11}{|c|}{ (2) } \\
\hline \multirow[t]{4}{*}{ Oregon } & Rogue Valley & Pear & 3 & 3 of 20 & 0 of 20 & 2 of 20 & Yes & 3.3 & 1 & Light \\
\hline & Hood River Valley & Pear & 6 & 6 of 30 & 6 of 30 & 7 of 25 & Yes & 3.3 & 2 & Light \\
\hline & Hood River Valley & Apple & 2 & 0 of 8 & 2 of 8 & 4 of 8 & Yes & 2.2 & 1 & Light \\
\hline & Walla Walla Valley & Apple & 4 & 0 of 20 & 4 of 20 & 11 of 20 & Yes & 3.3 & 3 & Light \\
\hline California & Lake County & Pear & 4 & 2 of 15 & 2 of 15 & 1 of 15 & Yes & 1.2 & 1 & Light \\
\hline \multirow[t]{3}{*}{ Washington } & Okanogan Valley & Pear & 1 & 0 of 4 & 0 of 6 & 2 of 4 & Yes & 3.8 & 1 & Light \\
\hline & Wenatchee Valley & Pear & 2 & 0 of 10 & 0 of 10 & 0 of 10 & No & - & 0 & - \\
\hline & Columbia Basin & Apple & 3 & 0 of 15 & 0 of 15 & 0 of 10 & No & - & 3 & Light to mod \\
\hline Utah & Utah County & Apple & 6 & 11 of $19^{\mathrm{h}}$ & 19 of $25^{\mathrm{h}}$ & 10 of $18^{\mathrm{h}}$ & Yes & 3.4 & 7 & Mod to heavy \\
\hline \multicolumn{11}{|l|}{2010} \\
\hline Oregon & Rogue Valley & Pear & 2 & 0 of 12 & 0 of 12 & 0 of 12 & No & 1.5 & 0 & _- \\
\hline California & Sutter County & Pear & 6 & 4 of 30 & 0 of 30 & 0 of 30 & Yes & 2.0 & 0 & - \\
\hline California & Lake County & Pear & 5 & 0 of 30 & 0 of 30 & 20 of 40 & Yes & - & 0 & - \\
\hline \multirow[t]{2}{*}{ Washington } & Okanogan Valley & Pear & 1 & 2 of 3 & 0 of 5 & - & No & - & 1 & Light \\
\hline & Yakima Valley & Apple & 9 & 0 of 30 & 2 of 30 & - & Yes & 1.6 & 6 & Light \\
\hline Summary & $\ldots$ & $\ldots$ & 60 & $\begin{array}{l}28 \text { of } 276 \\
(10 \%)\end{array}$ & $\begin{array}{l}38 \text { of } 285 \\
(13 \%)\end{array}$ & $\begin{array}{l}64 \text { of } 227 \\
(28 \%)\end{array}$ & $\ldots$ & 2.8 & 28 & $\ldots$ \\
\hline
\end{tabular}

a The 100-flower cluster samples (approximately 600 flowers per sample) were washed in 1.5 liter (2008) or 0.3 (2009 and 2010) of water in a resealable plastic bag.

b Number of positive LAMP assays of total 100-flower cluster samples; - indicates not sampled.

${ }^{\mathrm{c}}$ Indicates if E. amylovora was recovered from the washes of 100-flower cluster samples after dilution plating onto CCT medium (9).

d Average $\log _{10}$ population size of E. amylovora (CFU per flower) recovered from the wash of 100 -flower cluster samples.

${ }^{\mathrm{e}}$ Number of orchards with fire blight.

${ }^{\mathrm{f}}$ Disease severity in orchards with fire blight. Range of disease ratings applied to the orchards: light $=1$ strike per tree, moderate (mod) $=2$ to 5 strikes per tree, and heavy $\geq 6$ strikes per tree.

g Positive detection by LAMP required a fourfold speedvac concentration of extracted DNA.

${ }^{\text {h }}$ In Utah, one 100-flower cluster sample was collected from each orchard daily over a period to 10 to 12 days; dates were grouped into approximate stage of bloom. 
(163 of 195) obtained for the 100-flower cluster samples during periods when the weather-based model, Cougarblight, predicted at least moderate risk (index values $>225$ ). Similarly, 83 of 121 positive LAMP assays occurred on days when the CougarBlight index was below moderate risk although, in most cases, these samples were from orchards with a recent history of fire blight and, in some cases, the risk index had been at or above "moderate risk" shortly before the sample date. These inconsistencies relate back to our guiding rationale, which was that fire blight management could be refined and improved if variation in epiphytic populations of the pathogen could be readily measured. To this end, cooperating growers provided positive feedback on the value of information from the LAMP assay, with several reporting that a positive assay result, especially early in bloom, caused an intensification of their fire blight control efforts. In contrast, one cooperating pear grower used information from LAMP assays to withhold a protective spray (correctly) after negative results were weighed with the current risk of disease as determined by a forecasting model.

Over the period of this study, in part because we interacted with numerous individuals who made day-to-day decisions on disease control, we became more confident that a method of knowing the

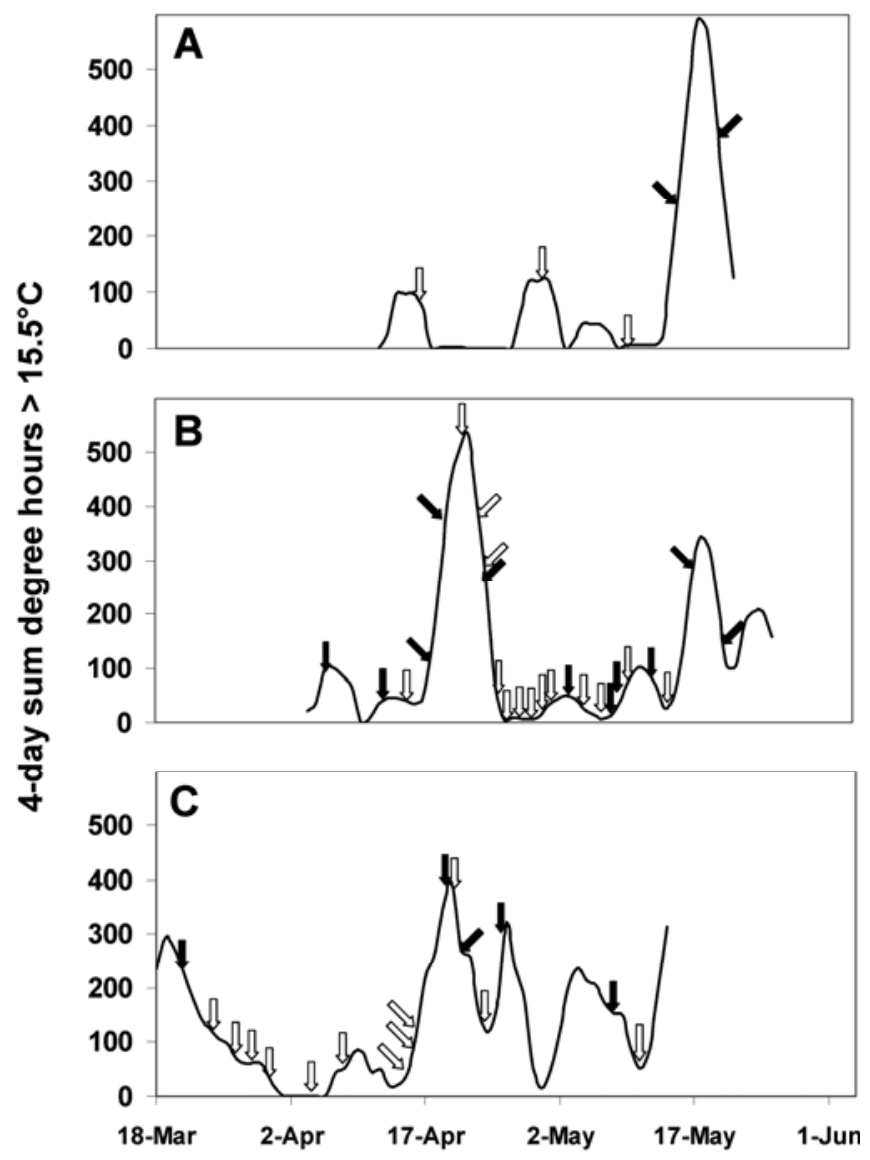

Fig. 2. Seasonal summaries of weather-based assessments of fire blight risk (Cougarblight model; 30) in relation to detection of Erwinia amylovora by loopmediated isothermal amplification (LAMP) assay of washes of pear and apple flowers sampled from commercial orchards in the Pacific Northwest region of the United States. Open arrows indicate no detection of $E$. amylovora by LAMP on the corresponding date, and solid arrows indicate that at least one LAMP assay performed on a 100-flower cluster sample was positive for E. amylovora. Cougarblight provides a 4-day moving sum of degree hours $>15.5^{\circ} \mathrm{C}\left(60^{\circ} \mathrm{F}\right)$; values of this index are used to assess the likelihood that epiphytic populations of $E$. amylovora have developed in pear and apple flowers (30). Index values shown in each panel are a composite from temperature data (see Materials and Methods) measured at each of production areas sampled that season: A, 2008; Rogue and Hood River Valleys of Oregon; B, 2009, Rogue and Hood River Valleys of Oregon, Lake County, CA, and Yakima, Wenatchee, and Okanogan Valleys of Washington; and C, 2010, Rogue Valley of Oregon, Lake and Sutter Counties, CA, and Yakima and Okanogan Valleys of Washington. presence or absence of the pathogen (a LAMP assay or a detection technology of similar sensitivity) could provide information useful for management of fire blight. We were unconvinced, however, that a centralized laboratory facility was the best model for providing this service to orchard managers. We (including cooperators) experienced several logistical problems stemming from withindistrict dynamics of pear and apple bloom, the rapid development of epiphytic populations of E. amylovora when temperature conditions were favorable, and the requirements for routine sampling of flowers, overnight shipping, and quick dissemination of LAMP results. Although equipment needs for LAMP assays are minimal, performing the assay requires personnel with excellent laboratory skills and a thorough understanding of the risk and prevention of molecular contamination (4). With good laboratory organization, we were able to process dozens of orchard samples simultaneously, and began and completed the floral washes and LAMP assays over a period of a few hours. Time for preparation and other fixed costs, however, such as those that would enable an efficient response over the relatively short period of pear and apple bloom, may discourage the involvement of for-profit service providers but perhaps not a grower-supported, regional extension facility. More promising are expected technological advances that offer the potential for point-of-care (i.e., on-site; 14) detection by nonprofessionals, such as the recent adaptation of LAMP to lateral-flow devices (36). In this regard, recent reviews $(14,17)$ make the case that future improvements in plant and veterinary disease diagnosis will depend on increased deployment of detection technologies "close to the suspect case of disease away from dedicated laboratory facilities" (14). With further development of pathogen-detection technologies for use on-site, the results of our study should prove useful to practitioners seeking to implement an early detection protocol for E. amylovora.

\section{Acknowledgments}

Support was provided by the Pacific Northwest Fresh Pear Committee, Washington Tree Fruit Research Commission, United States Department of Agriculture Western Regional-IPM Grant Program, and the Oregon State University Agricultural Experiment Station. We thank D. Belton, J. Bullion, S. Castagnoli, R. Elkins, C. Kaiser, M. Murray, H. Ostenson, F. Niederholzer, D. Rowley, R. Spotts, D. Suenram, D. Sugar, K. Wallace, A. Zediker, and B. Zoller, for assistance with commercial field sites; K. Evans, Utah State University, for performing the LAMP assays for the Utah samples; and pear and apple growers in California, Oregon, Utah, and Washington for orchard access and their assistance with sample collection and disease monitoring.

\section{Literature Cited}

1. Alvarez, A. M. 2004. Integrated approaches for detection of plant pathogenic bacteria and diagnosis of bacterial plant diseases. Annu. Rev. Phytopathol. 42:339-66.

2. Bereswill, S., Pahl, A., Bellemann, P., Wolfgang, Z., and Geider, K. 1992. Sensitive and species-specific detection of Erwinia amylovora by polymerase chain reaction analysis. Appl. Environ. Microbiol. 58:3522-3526.

3. Billing E. 2000. Fire blight risk assessment systems and models. Pages 293318 in: Fire Blight: The Disease and Its Causative Agent, Erwinia amylovora. J. L. Vanneste, ed. CAB International, London.

4. Boehme, C. C., Nabeta, P., Henostroza, G., Raqib, R., Rahim, Z., Gerhardt, M., Sanga, E., Hoelscher, M., Notomi, T., Hase, T., and Perkins, M. D. 2007. Operational feasibility of using loop-mediated isothermal amplification for diagnosis of pulmonary tuberculosis in microscopy centers of developing countries. J. Clin. Microbiol. 45:1936-1940.

5. Covey, R. P. 1988. The significance of secondary bloom to fire blight development on Bartlett pears in eastern Washington. Plant Dis. 72:911.

6. Freund, J. E., and Wapole, R. E. 1987. Mathematical Statistics, 4th ed. Prentice-Hall, Inc., Englewood Cliffs, NJ.

7. Gorris, M .T., Cambra, M., Llop, P., López, M. M., Lecomte, P., Chartier, R., and Paulin, J. P. 1996. A sensitive and specific detection of Erwinia amylovora based on the ELISA-DASI enrichment method with monoclonal antibodies. Acta Hortic. 411:41-45.

8. Hirano, S. S., Nordheim, E. V., Arny, D. C., and Upper, C. D. 1982. Lognormal distribution of epiphytic bacterial populations on leaf surfaces. Appl. Environ. Microbiol. 44:695-700.

9. Ishimaru, C. A., and Klos, E. J. 1984. New medium for detecting Erwinia amylovora and its use in epidemiological studies. Phytopathology 74:13421345.

10. Johnson, K. B., Sawyer, T. L., Stockwell, V. O., and Temple, T. N. 2009. Implications of pathogenesis by Erwinia amylovora on stigmas of rosaceous flowers to biological control of fire blight. Phytopathology 99:128-138. 
11. Johnson, K. B., and Stockwell, V. O. 1998. Management of fire blight: a case study in microbial ecology. Annu. Rev. Phytopathol. 36:227-248.

12. Johnson, K. B., Stockwell, V. O., Burgett, D. M., Sugar, D., and Loper, J. E. 1993. Dispersal of Erwinia amylovora and Pseudomonas fluorescens by honey bees to apple and pear blossoms. Phytopathology 83:478-484.

13. Kikuchi, T., Aikawa, T., Oeda, Y., Karim, N., and Kanzaki, N. 2009. A rapid and precise diagnostic method for detecting the pinewood nematode Bursaphelenchus xylophilus by loop-mediated isothermal amplification. Phytopathology 99:1365-1369.

14. King, D. P., Ferris, N. P., Tomlinson, J. A., and Boonham, N. 2010. Plant and veterinary disease diagnosis: a generic approach to the development of field tools for rapid decision making? EPPO Bull. 40:34-39.

15. Kritzman, G., Shwartz, H., Marcus, R., Manulis, S., Klietman, F., Oppenheim, D., Ziberstaine, M., and Shtienberg, D. 2003. Testing a rapid diagnostic medium for Erwinia amylovora and development of a procedure for sampling blossoms in pear orchards. Phytopathology 93:931-940.

16. Kubota, R., Vine, B. G., Alvarez, A. M., and Jenkings, D. M. 2008. Detection of Ralstonia solanacearum by loop-mediated isothermal amplification. Phytopathology 98:1045-1051.

17. Lievens, B., and Thomma, B. P. H. J. 2005. Recent developments in pathogen detection arrays: implications for fungal plant pathogens and use in practice. Phytopathology 95:1374-1380.

18. Llop, P., Donat, V., Rodríguez, M. Cabrefiga, J., Ruz, L., Palomo, J. L., Montesinos, E., and López, M. M. 2006. An indigenous virulent strain of Erwinia amylovora lacking the ubiquitous plasmid pEA29. Phytopathology 96:900-907.

19. Louws, F. J., Rademaker, J. L. W., and de Bruijn, F. J. 1999. The three Ds of PCR-based genomic analysis of phytobacteria: diversity, detection, and disease diagnosis. Annu. Rev. Phytopathol. 37:81-125.

20. Ma, Z., and Michailides, T. J. 2005. Advances in understanding molecular mechanisms of fungicide resistance and molecular detection of resistant genotypes in phytopathogenic fungi. Crop Prot. 24:853-863.

21. MacManus, P. S., and Jones, A. L. 1995. Detection of Erwinia amylovora by nested PCR and PCR-dot-blot and reverse blot hybridizations. Phytopathology 85:618-623.

22. McGhee, G. C., and Jones, A. L. 2000. Complete nucleotide sequence of ubiquitous plasmid pEA29 from Erwinia amylovora strain Ea88: gene organization and intraspecies variation. Appl. Environ. Microbiol. 66:48974907.

23. Miller, T. D., and Schroth, M. N. 1972. Monitoring the epiphytic population of Erwinia amylovora on pear with a selective medium. Phytopathology
62:1175-1182.

24. Mori, Y., and Notomi, T. 2009. Loop-mediated isothermal amplification (LAMP): a rapid, accurate, and cost-effective diagnostic method for infectious diseases. J. Infect. Chemother. 15:62-69.

25. Nie, X. 2005. Reverse transcription loop-mediated isothermal amplification of DNA for detection of Potato virus Y. Plant Dis. 89:605-610.

26. Niessen, L., and Vogel, R. F. 2010. Detection of Fusarium graminearum DNA using a loop-mediated isothermal amplification (LAMP) assay. Int. J. Food Microbiol. 140:183-191.

27. Notomi, T., Okayama, H., Masubuchi, H., Yonekawa, T., Watanabe, K., Amino, N., and Hase, T. 2000. Loop-mediated isothermal amplification of DNA. Nucleic Acids Res. 28:e63.

28. Pusey, P. L., Stockwell, V. O., and Mazzola, M. 2009. Epiphytic bacteria and yeasts on apple blossoms and their potential as antagonists of Erwinia amylovora. Phytopathology 99:571-581.

29. Salm, H., and Geider, K. 2004. Real-time PCR for detection and quantification of Erwinia amylovora, the causal agent of fire blight. Plant Pathol 53:602-610.

30. Smith, T. J. 1999. Report on the development and use of Cougarblight 98C: a situation-specific fire blight risk assessment model for apple and pear Acta Hortic. 489:429-433.

31. Steiner, P. W. 2000. Integrated orchard and nursery management for the control of fire blight. Pages 339-358 in: Fire Blight: The Disease and Its Causative Agent, Erwinia amylovora. J. L. Vanneste, ed. CAB International, London.

32. Stockwell, V. O., Johnson, K. B., and Loper, J. E. 1998. Establishment of bacterial antagonists of Erwinia amylovora on pear and apple blossoms as influenced by inoculum preparation. Phytopathology 88:506-513.

33. Stockwell, V. O., McLaughlin, R. J., Henkels, M. D., Loper, J. E., Sugar, D. and Roberts, R. G. 1999. Epiphytic colonization of pear stigmas and hypanthia by bacteria during primary bloom. Phytopathology 89:1162-1168.

34. Thomson, S. V. 2000. Epidemiology of fire blight. Pages 9-36 in: Fire Blight: The Disease and Its Causative Agent, Erwinia amylovora. J. L. Vanneste, ed. CAB International, London.

35. Tomlinson, J., and Boonham, N. 2008. Potential of LAMP for detection of plant pathogens. In: CAB Reviews: Perspectives in Agriculture, Veterinary Science, Nutrition and Natural Resources, No. 66.

36. Tomlinson, J. A., Dickinson, M. J., and Boonham, N. 2010. Rapid detection of Phytophthora ramorum and P. kernoviae by two-minute DNA extraction followed by isothermal amplification and amplicon detection by generic lateral flow device. Phytopathology 100:143-149. 